\title{
An after-market, five-port vertical beam line extension for the PETtrace
}

\author{
Barnhart, T. E.; Engle, J. W.; Severin, Gregory; Valdovinos, H. F.; Gagnon, K.; Nickles, R. J.
}

Published in:

AIP Conference Proceedings - American Institute of Physics

Link to article, DOI:

$10.1063 / 1.4773932$

Publication date:

2012

Document Version

Publisher's PDF, also known as Version of record

Link back to DTU Orbit

Citation (APA):

Barnhart, T. E., Engle, J. W., Severin, G., Valdovinos, H. F., Gagnon, K., \& Nickles, R. J. (2012). An aftermarket, five-port vertical beam line extension for the PETtrace. AIP Conference Proceedings - American Institute of Physics, 1509(1), 21-24. https://doi.org/10.1063/1.4773932

\section{General rights}

Copyright and moral rights for the publications made accessible in the public portal are retained by the authors and/or other copyright owners and it is a condition of accessing publications that users recognise and abide by the legal requirements associated with these rights.

- Users may download and print one copy of any publication from the public portal for the purpose of private study or research.

- You may not further distribute the material or use it for any profit-making activity or commercial gain

- You may freely distribute the URL identifying the publication in the public portal 


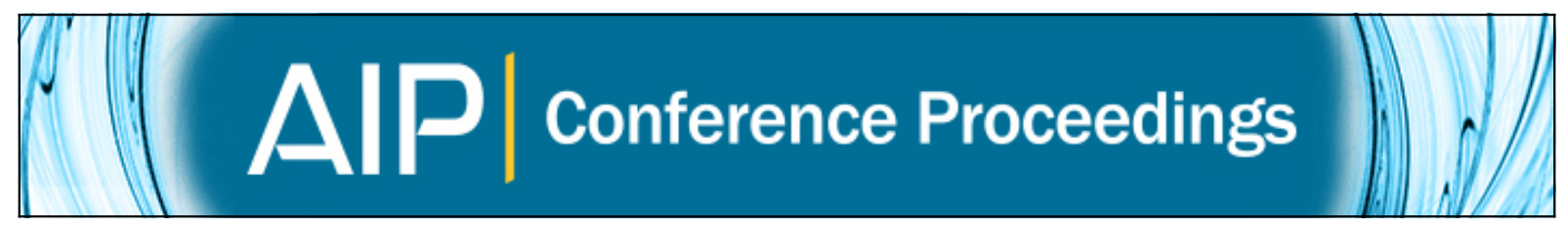

\section{An after-market, five-port vertical beam line extension for the PETtrace}

T. E. Barnhart, J. W. Engle, G. W. Severin, H. F. Valdovinos, K. Gagnon, and R. J. Nickles

Citation: AIP Conference Proceedings 1509, 21 (2012); doi: 10.1063/1.4773932

View online: http://dx.doi.org/10.1063/1.4773932

View Table of Contents: http://scitation.aip.org/content/aip/proceeding/aipcp/1509?ver=pdfcov

Published by the AIP Publishing

\section{Articles you may be interested in}

A transverse emittance and acceptance measurement system in a low-energy beam transport linea)

Rev. Sci. Instrum. 85, 02A735 (2014); 10.1063/1.4858175

The cyclotron laboratory and the RFQ accelerator in Bern

AIP Conf. Proc. 1530, 189 (2013); 10.1063/1.4812922

The new bern PET cyclotron, its research beam line, and the development of an innovative beam monitor detector

AIP Conf. Proc. 1525, 144 (2013); 10.1063/1.4802308

Routine $18 \mathrm{~F}$ - production with $180 \mu \mathrm{A}$ to $200 \mu \mathrm{A}$ target beam current on a GE PETtrace 800 cyclotron AIP Conf. Proc. 1509, 66 (2012); 10.1063/1.4773942

Five Years of Cyclotron Radioisotope Production Experiences at the First PET-CT in Venezuela AIP Conf. Proc. 947, 67 (2007); 10.1063/1.2813874 


\title{
An After-Market, Five-Port Vertical Beam Line Extension For The PETtrace
}

\author{
T.E. Barnhart ${ }^{\mathrm{a}}$, J.W. Engle ${ }^{\mathrm{b}}$, G.W. Severin ${ }^{\mathrm{c}}$, H.F. Valdovinos ${ }^{\mathrm{a}}$, K. \\ Gagnon $^{\text {d }}$ and R.J. Nickles ${ }^{\mathrm{a}}$ \\ ${ }^{a}$ Department of Medical Physics, University of Wisconsin, Madison, WI, USA \\ ${ }^{b}$ Los Alamos National Lab, Los Alamos, NM, USA \\ ${ }^{c}$ Hevesy Laboratory, Danish Technical University, Risø, Denmark \\ ${ }^{d}$ Department of Radiology, University of Washington, Seattle, WA, USA
}

\begin{abstract}
Most commercial cyclotrons intended for medical isotope production provide a limited number of beam ports crowded into a minimal vault space. Taking advantage of our new lab construction, we planned and installed a beam-line on port \#2 of our GEMS PETtrace to bring beam to an additional 5 target positions. These are oriented in the vertical plane, with the downward directed beam well suited for molten target substrates.
\end{abstract}

Keywords: beam optics, radionuclide production

PACS: 29.20.dg, 29.27.Eg, 29.27.Fh

\section{INTRODUCTION}

The GEMS PETtrace is well matched to serve the clinical needs for conventional PET radionuclides: ${ }^{11} \mathrm{C},{ }^{13} \mathrm{~N},{ }^{15} \mathrm{O}$ and ${ }^{18} \mathrm{~F}$. With $100 \mu \mathrm{A}$ of $16 \mathrm{MeV}$ protons and $80 \mu \mathrm{A}$ of $8 \mathrm{MeV}$ deuterons directed onto 6 beam ports, the needs for aqueous ${ }^{18} \mathrm{~F}^{-},{ }^{13} \mathrm{~N}-$ ammonia, ${ }^{15} \mathrm{O}$-gases and ${ }^{11} \mathrm{C}$-methylating agents are easily met. However, the UW PET research program calls for an expanded list, including ${ }^{10} \mathrm{C}$, electrophilic ${ }^{18} \mathrm{~F}$ and ${ }^{34 \mathrm{~m}} \mathrm{Cl}$, as well as the entire $3 \mathrm{~d}$-shell of transition metals. These synthons require highly specialized targets supporting corrosive and often molten target materials. To accommodate this expanded list, a beam line extension was designed and built by National Electrostatics Corporation (Middleton, WI) with 5 beam ports at $0^{\circ}, \pm 15^{\circ}$ and $\pm 30^{\circ}$ oriented in the vertical plane. The critical specifications called for beam optics to focus the beam onto a $5 \mathrm{~mm}$ FWHM beam strike, anticipating costly enriched isotopes. The downward-direct ports are intended for targets, some of which are listed in Table 1 with melting points that need gravity to confine the molten target substrates in a horizontal configuration.

\section{MATERIALS AND METHODS}

In 2009, the PETtrace (\#144) was bunkered in new space in the UW Institute of Medical Research. All targets are made in house. The raised placement and service trench encircling the cyclotron were designed to permit clear access all around, as well 
TABLE 1. Problematic target substrates that benefit from a vertical beam strike on the melt.

\begin{tabular}{lcc}
\hline Reaction & Target Substrate & MP $\left({ }^{\circ} \mathbf{C}\right)$ \\
\hline${ }^{10} \mathrm{~B}(\mathrm{p}, \mathrm{n}){ }^{10} \mathrm{C}$ & ${ }^{10} \mathrm{~B}_{2} \mathrm{O}_{3}$ & 450 \\
${ }^{34} \mathrm{~S}(\mathrm{p}, \mathrm{n}){ }^{34 \mathrm{~m}} \mathrm{Cl}$ & $\mathrm{S}$ & 112 \\
${ }^{44} \mathrm{Ca}(\mathrm{p}, \mathrm{n}){ }^{44} \mathrm{Sc}$ & ${ }^{\mathrm{nat}} \mathrm{Ca}$ & 839 \\
$\left.{ }^{69} \mathrm{Ga}(\mathrm{p}, \mathrm{n})\right)^{69} \mathrm{Ge}$ & ${ }^{\mathrm{nata}} \mathrm{Ga}$ & 39 \\
${ }^{76} \mathrm{Se}(\mathrm{p}, \mathrm{n}){ }^{76} \mathrm{Br}$ & $\mathrm{Se}$ & 217 \\
${ }^{86} \mathrm{Sr}(\mathrm{p}, \mathrm{n}){ }^{86} \mathrm{Y}$ & $\mathrm{Sr}$ & 769 \\
${ }^{124} \mathrm{Te}(\mathrm{p}, \mathrm{n}){ }^{124} \mathrm{I}$ & $\mathrm{Te}$ & 452 \\
\hline
\end{tabular}

as 12 feet of clear run from the PETtrace beam ports for the future beam line. Specifications were sent out to three bidders, and the contract was let to NEC in 2010. Their careful beam optics calculations, starting from the emittance characteristics provided by GEMS for port \#2 (upward directed by $2.5^{\circ}$ ), led to five elements shown in Figure 1:

- $\mathrm{a} \pm 1^{\circ}$ horizontal steerer, followed by

- a few degree vertical steerer to bring the beam to horizontal for entry into

- a quadrupole doublet, focusing the beam through

- a high-power quad slit and drift tube, leading to

- the 5-port, double-focusing switching magnet, supporting the new targets.

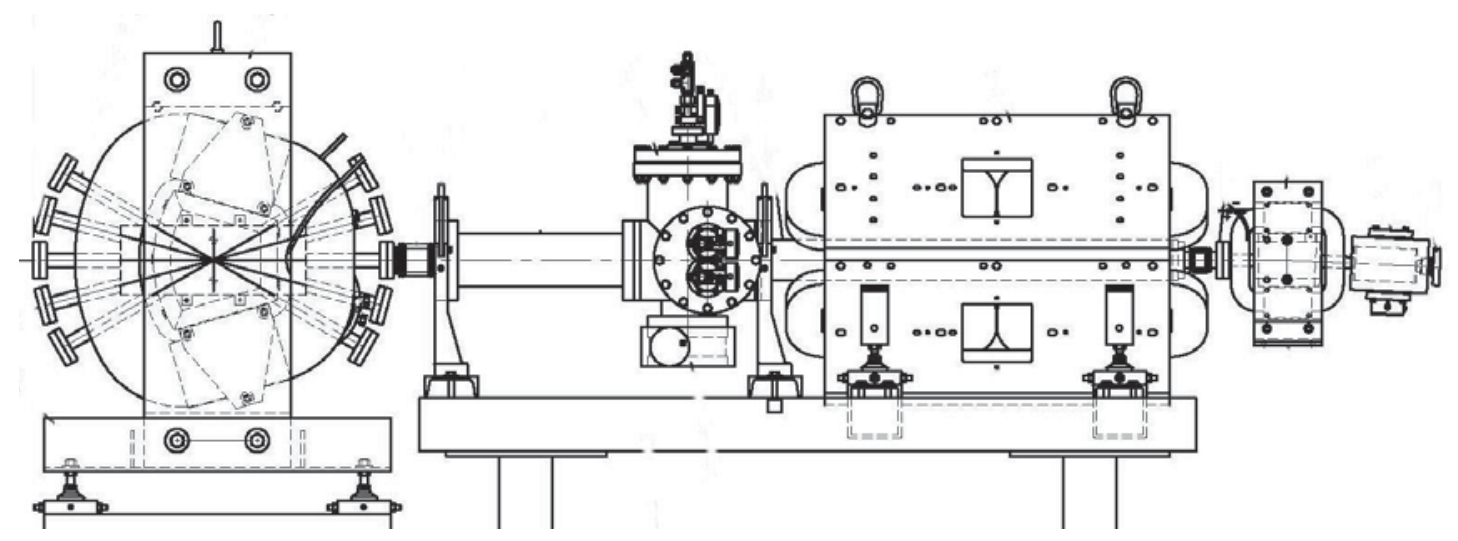

FIGURE 1. Beam line schematic.

The off-axis beam ports at $\pm 15^{\circ}$ and $\pm 30^{\circ}$ have colinear view ports for visual monitoring with IRtc and CCD TV telemetry. A USB color TV camera (ImagingSource DFK21AU618; 640x480, equipped with a varifocal lens) is mounted on the $150^{\circ}$ viewport to image the $-30^{\circ}$ target, shown in Figure 2. 


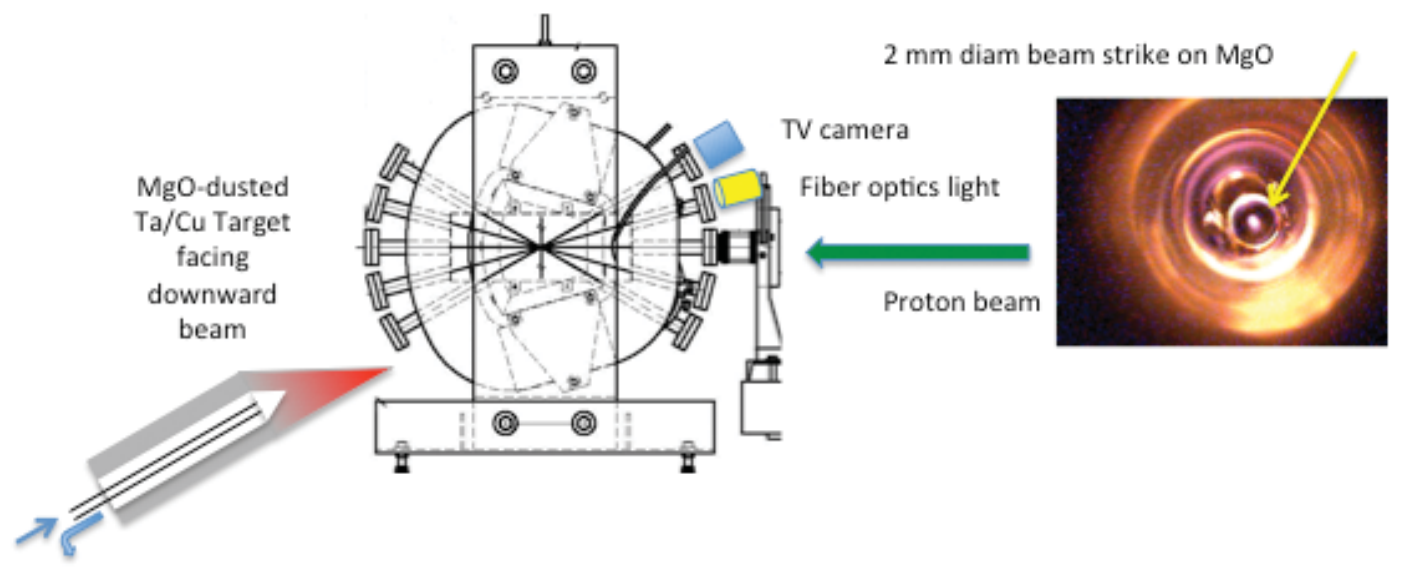

FIGURE 2. Several microamps of $16 \mathrm{MeV}$ proton focused onto a horizontal surface dusted with $\mathrm{MgO}$ to provide a visual signal of the $2 \mathrm{~mm}$ (FWHM) beam strike.

\section{RESULTS AND DISCUSSION}

A Balzers-Pfeiffer TPU 240 turbopump holds the vacuum to mid- $10^{-7} \mathrm{~mm} \mathrm{Hg}$. Installation and alignment made use of a laser mounted on an overhead bridge crane. Irradiations employ the service laptop for cyclotron control, with manual control of the steerers, quads and switching magnet power supplies. The fine control and stability of these supplies are essential, since a change of $100 \mathrm{~mA}$ on the $55 \mathrm{amp}$ switching magnet current swings the beam over the entire "vertical" target span at $30^{\circ}$. Irradiation parameters, as well as prompt neutron and gamma signals are monitored by LabView . Correlating changes of the neutron rate against the visual signal of the centered beam strike on the MgO-dusted target builds a sixth sense needed to hit small depositions of enriched materials. Transmission from the PETtrace stripper to final target position is $\approx 77 \%$ with losses mainly at the short length of $25 \mathrm{~mm}$ ID entrance to the first vertical beam steerer. Until we improve this transmission, we are limiting the beam at our final target positions to $50 \mu \mathrm{A}$.

\section{CONCLUSIONS}

Outfitting the modern cyclotron with multiple beam ports has taken various pathways: magnetic beam switching, Gatling-gun turrets, linear slide arrays, wobbled flexible bellows and in-line series targets. The freedom afforded by our new construction, and the need to present our molten targets to a down-ward-directed beam led us to this beam line configuration. Our experience with a truly vertical beam line following a $90^{\circ}$ switching magnet on our legacy RDS 112 has convinced us $(1,2)$ that the gravitational containment of corrosive liquid targets is essential. The choice of a vertically angled beam permits even higher power irradiation while maintaining a horizontal surface. 


\section{ACKNOWLEDGMENTS}

The support of the NCI Training Grant T32 CA09206 and the skills of the staff at National Electrostatics Corporation are gratefully acknowledged.

\section{REFERENCES}

1. R. J. Nickles, J. Nucl. Med. 32, 1091 (1991).

2. M. Jensen, G. Wolber, J. Nickles and A. Runz, "Gravity Can Offer Help: Stable Production of C-10 by Bombarding a Molten Sea of Boron Oxide with a Vertical Proton Beam" in Proceedings of the IX Workshop on Targetry and Target Chemistry, Turku, Finland, 2002, pp. 58-61. 